25.Літошенко О.С. Адміністративна відповідальність в системі юридичної відповідальності : дис. ... канд.. юрид. наук : 12.00.07 / Нац. економ. у-нт ім. Вадима Гетьмана. Київ, 2004. 199 c.

26.Кодекс України про адміністративні правопорушення від 07 грудня 1984 р. Відомості Верховної Ради УРСР. 1984. Додаток до № 51. Ст. 1123.

27. Хаманева Н.Ю. Проблемы административной ответственности. Административная ответственность / отв. ред. И.Л. Бачило, Н.Ю. Хаманева. Москва, 2001. С. 5-9.

28.Заярний О.А. Суб'єкт адміністративних інформаційних правопорушень: поняття та особливості. Адміністративне право і проиес. 2015. № 2. С. 86-104.

29.Заярний О.А. Об’єктивна сторона адміністративного інформаційного правопорушення: поняття, структура та особливості правової кваліфікації. Адміністративне право i проичес. 2015. № 3 (13). С. 134-149.

30.Білоцерковець Н.В. Електронна печатка як один із видів електронних довірчих послуг: поняття, ознаки та функції. Актуальні проблеми правових наук в євро інтеграційному вимірі: Матеріали міжнародної науково-практичної конференції (м. Харків, 15-16 грудня 2017 р.). Харків, 2017. Ч. 2. С. 23-26.

ГОРІНОВ П. В., аспірант

(Національний авіаційний університет)

УДК 342.95

DOI https://doi.org/10.32842/2078-3736-2019-6-2-4

\title{
ЄДНІСТЬ СИСТЕМИ СУБ'ЄКТІВ ПРИЗНАЧЕННЯ НА ПОСАДУ СУДДІ ЯК ГАРАНТІЯ НЕЗАЛЕЖНОСТІ СУДОВОЇ ВЛАДИ
}

Стаття присвячена обгрунтуванню необхідності забезпечення єдності суб' єктів призначення на посаду судді в контексті гарантування незалежності судової влади, формулюванню на цій основі пропозицій щодо вдосконалення чинного законодавства про судоустрій і статус суддів. Обгрунтовано, що у випадку поєднання в одному суб'єкті публічної влади, що характеризується єдиною метою діяльності (забезпечення незалежності судової гілки влади) добір кандидатів на посаду судді та відповідні подальші процедури здійснювалися б із урахуванням не тільки власне процедур, але й зазначеної мети. Неврахування такої мети означало би протиправний характер відповідної діяльності.

Виходячи 3 вказаного, наведений у юридичній літературі поділ суб'єктів формування суддівського корпусу за комплексним критерієм мети та правових наслідків діяльності на попередні (кваліфікаційні комісіі) та безпосередні (суб'єкти остаточного призначення на посаду судді) необхідно визнати таким, що поступово втрачає свою актуальність як із наукового, так і з практичного погляду, не відповідає визнаним міжнародним стандартам побудови суб’ єктів призначення на посаду судді.

Реалізація передання повноважень ВККС України щодо проведення добору кандидатів для призначення на посаду судді, у т. ч. організації проведення щодо них спеціальної перевірки відповідно до закону та прийняття кваліфікаційного іспиту передбачає потребує внесення комплексних змін до чинного зако-

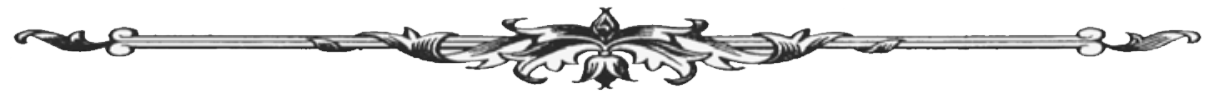


нодавства про судоустрій. Втім, одним 3 перших кроків необхідно визначити наступні: виключення із Закону «Про судоустрій і статус суддів» глави 3 розділу 5 та перенесення відповідних положень до Закону «Про Вищу раду правосуддя»; внесення змін до власне норм цієї глави виходячи зі статусу ВККС України як структурного підрозділу ВРП; внесення змін до інших положень Закону «Про судоустрій і статус суддів» 3 метою врахування змін у статусі ВККС України.

Ключові слова: незалежність суду, незалежність судді, призначення на посаду судді, гарантії незалежності суду, судоустрій.

The article is devoted to substantiating the need to ensure the unity of the subjects appointed to the position of judge in the context of guaranteeing the independence of the judiciary, to formulate on this basis proposals to improve the current legislation on the judiciary and the status of judges. It is justified that in the case of a unification of a public authority in one entity characterized by the sole purpose of activity (ensuring the independence of the judicial branch), the selection of candidates for the post of judge and the corresponding subsequent procedures would be carried out not only for the proper procedures but also for the stated purpose. Disregard of such purpose would indicate the unlawful nature of the activity concerned.

Based on the above, the division of the subjects of formation of the judicial corps in the legal literature on the complex criterion of purpose and legal consequences of activity on the preliminary (qualifying commissions) and direct (subjects of final appointment to the position of judge) must be recognized as gradually losing its relevance, both scientifically and practically, does not meet recognized international standards for the appointment of judges.

The implementation of the transfer of powers of the High Qualifications Commission of Judges of Ukraine to conduct the selection of candidates for the appointment of a judge, including the organization of conducting a special examination for them in accordance with the law and passing the qualification examination, requires complex amendments to the current legislation on the judiciary. However, one of the first steps is to identify the following: exclusion from the law "On the Judiciary and Status of Judges" Chapter 3 of Part 5 and transposition of the relevant provisions into the law "About the High Council of Justice"; introducing changes to the norms of this chapter based on the status of the High Qualifications Commission of Judges of Ukraine as a structural unit of the High Council of Justice; amending other provisions of the Law "On the Judiciary and Status of Judges" in order to take into account changes in the status of the High Judicial Qualifications Commission of Ukraine.

Key words: court independence, independence of a judge, appointment to a position of a judge, guarantees of independence of a court, judiciary.

Вступ. Численні недоліки у діяльності Вищої кваліфікаційної комісії суддів України (далі - ВККС України) та Вищої ради правосуддя (далі -ВРП) зумовили підписання Президентом України проекту Закону України, яким передбачається, в т. ч. реорганізація діяльності вказаних суб'єктів владних повноважень [1]. Втім, аналіз засад цієї реорганізації свідчить про актуальність врахування міжнародних стандартів діяльності подібних суб'єктів владних повноважень. Одним із таких стандартів $\epsilon$, зокрема, єдність суб'єктів владних повноважень, відповідальних за формування високопрофесійного суддівського корпусу, та суб'єктів, що $\epsilon$ відповідальними за забезпечення незалежності судової влади. Втім, сьогодні зберігається становище ВККС України як окремого суб'єкта публічної влади у сфері судоустрою порівняно із ВРП. Саме зазначене, з-поміж інших чинників, призводить до численних недоліків у справі добору суддів і призначення їх на посаду.

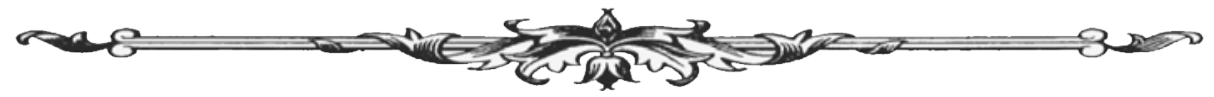


Питання правового статусу суб'єктів призначення на посаду судді отримали в юридичній літературі достатньо широку увагу. Зокрема, слід вказати на наукові напрацювання таких вчених, як І.С. Марочкін, Л.М. Москвич, С.В. Прилуцький, В.Е. Теліпко та багатьох інших дослідників. Втім, саме питання співвідношення правового статусу суб'єкта добору кандидатів на посаду судді та суб'єкта призначення на посаду судді (ВРП та інших подібних суб’єктів, Президента України) не були предметом належної уваги науковців.

Постановка завдання. Метою статті $є$ обгрунтування необхідності забезпечення єдності суб'єктів призначення на посаду судді в контексті гарантування незалежності судової влади, формулювання на цій основі пропозицій щодо вдосконалення чинного законодавства про судоустрій і статус суддів.

Результати дослідження. Тісний взаємозв'язок родових і видових категорій проявляється, передусім, у їх спільних ознаках. Виокремлення видових категорій не виключає врахування ширшого контексту, зокрема - властивостей інших видових категорій, а також об’єднуючого їх спільного критерію. Тому дослідження міжнародних стандартів формування професійного корпусу суддів передбачає опрацювання зазначених стандартів стосовно гарантій незалежності суддів загалом.

Необхідно вказати на прийняту сьогодні низку міжнародних документів, що містять міжнародні стандарти забезпечення незалежності суду та суддів. Такими є: «Основні принципи незалежності судових органів» (1985р.), «Монреальська універсальна декларація щодо незалежності правосуддя» (1983 р.), «Статут суддів в Європі» (1997 р.) «Свропейська Хартія про статус суддів» (1998 р.), «Загальна хартія судді» (1999 р.), «Велика хартія суддів» (2010 р.) [2, с. 19, 27, 67, 106, 112, 115]. Необхідно відмітити вагому роль також рекомендаційних актів. Такими слід вказати: «Рекомендації щодо ефективного впровадження Основних принципів щодо незалежності судових органів» (прийняті резолюцією Економічної та соціальної Ради ООН 1989/60 та схвалені резолюцією Генеральної Асамблеї ООН 44/162 від 15 грудня 1889 р.); «Рекомендація CM/Rec (2010) 12 Комітету Міністрів Ради Європи державам-членам щодо суддів:незалежність, ефективність та обов'язки» (ухвалена Комітетом Міністрів Ради Європи 17 листопада 2010 р. на 1098 засіданні заступників міністрів); «Висновок № 1 (2001) Консультативної ради європейських суддів до уваги Комітету Міністрів Ради Свропи щодо стандартів незалежності судової влади та незмінюваності суддів»; Доповідь Європейської комісії «За демократію через право» (Венеціанської комісії) «Європейські стандарти в сфері судочинства - систематичний огляд»; «Доповідь Свропейської комісії «За демократію через право» (Венеціанської комісії) щодо незалежності судової системи, частина I: незалежність суду (прийнята Венеціанською комісією на 82-му пленарному засіданні (Венеція, 12-13 березня 2010 р.)» [2, с. 24, 41, 51, 70, 88] та деякі інші.

Крім того, істотне значення мають загальноприйняті стандарти прав людини, зафіксовані у таких документах, як: Загальна декларація прав людини (1948 р.) [3], Конвенція про захист прав людини і основоположних свобод (1950р.) (далі - Конвенція) [4] тощо.

Зокрема, у п. 1 ст. 6 Конвенції наголошується на праві кожного на захист своїх прав зокрема, незалежним судом. Термін «незалежність» щодо суду та суддів знайшов своє тлумачення у практиці Свропейського суду з прав людини у його численних рішеннях, зокрема: Бомартен проти Франції, Обермайєр проти Австрії, Шевроль проти Франції, Терра Вонінген Б.В. проти Нідерландів, Брайян проти Сполученого Королівства та ін. [5].

Незалежність і неупередженість суду передбачають: відсутність особистої заінтересованості у результатах розгляду справи, виконуваність рішення суду, неприпустимість підпорядкування іншим суб'єктам публічної влади при розгляді й вирішенні справи, неприпустимість поєднання в одному суб' єкті здійснення правосуддя функцій різних гілок влади.

Серед гарантій незалежності судді при здійсненні правосуддя на першому місці постає особливий порядок його призначення, а також припинення його повноважень чи звільнення (п. 1 ч. 5 ст. 48 Закону «Про судоустрій і статус суддів»). У зв’язку з наведеним доцільно навести один зі стандартів незалежності судді, передбачений рекомендаційним актом. Так, Київськими Рекомендаціями ОБСЕ щодо незалежності судової системи в

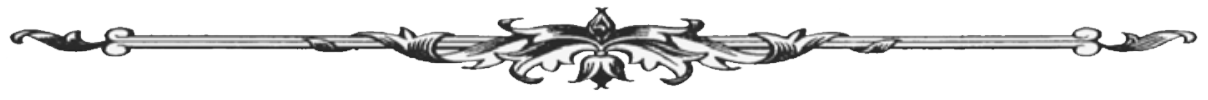


країнах Східної Європи, Південного Кавказу та Центральної Азії (Київ, 23-25 червня 2010 р.) передбачено необхідність створення особливого суб'єкта публічної влади для проведення іспитів з метою добору суддів, окрім випадків, встановлених законом. Контролюючі органи у такому випадку можуть перевіряти виключно дотримання таким суб'єктом публічної влади відповідних законодавчих процедур, а також законність прийняття рішень на основі дотримання таких процедур. Окремо наголошується не забезпеченні незалежності суб'єктів процедур призначення суддів на посаду від органів інших гілок влади, зокрема виконавчої (п. 3, 4 зазначених Рекомедацій) [2, с. 73].

У Великій хартії суддів, прийнятій 17 листопада 2010 р. у Страсбурзі, серед гарантій незалежності судової влади на першому місці відзначається забезпечення об'єктивності (зовнішньої вираженості) критеріїв відбору кандидатів на посаду судді. Крім того, вказується на необхідність поєднання в одному суб'єкті: суб'єкта прийняття таких рішень та суб'єкта відповідальності за збереження незалежності судової гілки влади. У цьому зв'язку необхідно звернути увагу на окремі положення вітчизняного законодавства у сфері судоустрою. Так, ВККС України, з-поміж іншого, проводить добір кандидатів для призначення на посаду судді, у тому числі організовує проведення щодо них спеціальної перевірки відповідно до закону та приймає кваліфікаційний іспит (п. 2 ч. 1 ст. 93 Закону «Про судоустрій і статус суддів»). ВРП діє для зокрема, забезпечення незалежності судової влади (ч. 1 ст. 1 Закону України «Про Вищу раду правосуддя» від 21 грудня 2016 р. № 1798-VIII (далі - Закон «Про Вищу раду правосуддя») [6]). ВРП може ухвалити рішення про відмову у внесенні Президентові України подання про призначення судді на посаду <...> тільки на підставі обгрунтованих відомостей <..> якщо: 1) такі відомості не були предметом розгляду ВККС України; 2) ВККС України не дала належної оцінки таким відомостям в межах процедури кваліфікаційного оцінювання щодо відповідного кандидата (ч. 4 ст. 37 Закону «Про Вищу раду правосуддя»). ВРП є окремим, визначеним органом державної влади із самостійним статусом (ч. 1 ст. 1 Закону «Про Вищу раду правосуддя»). ВККС України теж характеризується такими ознаками (ч. 1 ст. 92 Закону «Про судоустрій і статус суддів»).

Таким чином, забезпечення незалежності судової влади та здійснення добору кандидатів для призначення на посаду судді за національним законодавством здійснюється двома різними суб'єктами публічної влади: Вищою радою правосуддя та ВККС України відповідно. При цьому підстави для відмови у внесенні Президентові України подання про призначення судді на посадуне можуть бути застосовані якщо відповідні обставини були предметом розгляду ВККС України. Отже, хоча відповідне подання Президенту України вносить суб’єкт відповідальності за збереження незалежності судової гілки влади, але основне встановлення обставин справи щодо конкретного кандидата здійснюється іншим, окремими суб'єктом публічної влади. Причому його рішення є обов'язковим для ВРП.

Це дозволяє стверджувати про відповідальність ВККС України безпосередньо за дотримання процедур формування суддівського корпусу, але не за забезпечення незалежності судової гілки влади загалом. 3 огляду на, подекуди, недостатню чіткість критеріїв проведення кваліфікаційного оцінювання суддів [7], це спричиняє ризик невиправдано формального підходу при кваліфікаційному оцінюванні суддів, що констатується сьогодні у юридичних публікаціях [8;9].

Ефективним шляхом подолання зазначеного недоліку можна визначити впровадження окресленого міжнародного стандарту у національний правовий обіг шляхом зокрема передання функцій ВККС України щодо добору суддів до ВРП.

До прийняття Закону «Про Вищу раду правосуддя» відповідні функції виконувала Вища рада юстиції, призначенням якої визначалось формування високопрофесійного суддівського корпусу, що міг би належним чином здійснювати правосуддя [10, с. 925]. Втім, тоді актуальною була діяльність кваліфікаційних комісій та Вищої кваліфікаційної комісії України. Вища рада юстиції розглядалась у юридичній літературі як новела $[10$, с. 925 ; 11, с. 251]. С.В. Прилуцький розглядає Вищу раду юстиції як самостійний суб’єкт публічної влади в системі судової влади, що має централізований характер. При цьому основною

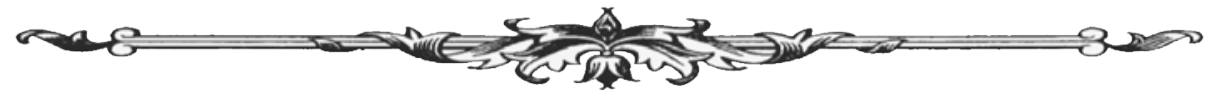


формою процедур зайняття посади судді визначається взаємодія Вищої ради юстиції та кваліфікаційних комісій. Завдяки наведеному досягається колегіальний характер прийняття рішень щодо призначення судді на посаду. Колегіальність розглядається як основна засада діяльності суб’єктів призначення судді на посаду [12, с. 96].

С.В. Прилуцький формулює класифікацію суб'єктів формування суддівського корпусу за комплексним критерієм мети та правових наслідків діяльності. Так, виділяються попередні суб'єкти та безпосередні суб'єкти. Попередні суб'єкти здійснюють добір і представляють кандидатів на посаду судді для подальшого призначення. Безпосередні мають повноваження щодо наділення чи позбавлення суддів повноважень. Основним завданням попередніх суб’єктів є збір і підготовка матеріалів щодо конкретного кандидата 3 метою подальшого вирішення питання щодо призначення його на посаду судді [12, с. 95]. У попередніх суб'єктах неважко вбачати кваліфікаційні комісії, а у безпосередніх - Вищу раду юстиції та Президента України, хоча С.В. Прилуцький безпосередньо цього не наводить.

Визнаючи актуальність і наукову значимість вказаних положень на момент їх формулювання, необхідно вказати, що збереження засади колегіальності можливо й при організації процедури призначення на посаду судді в рамках одного суб'єкта публічної влади - ВРП.

У разі поєднання в одному суб'єкті публічної влади, що характеризується єдиною метою діяльності (забезпечення незалежності судової гілки влади) добір кандидатів на посаду судді та відповідні подальші процедури здійснювалися б із урахуванням не тільки власне процедур, але й зазначеної мети. Неврахування такої мети означало би протиправний характер відповідної діяльності.

3 іншого боку, не можна не визнати, що зазначена передача функцій від ВККС України до ВРП вимагає внесення комплексних змін до чинного законодавства. Зокрема, добір кандидатів на посаду судді визначено на одному з перших місць серед повноважень цього органу, а отже, є іманентно властивим йому. За таких обставин виключення такого повноваження означало б по суті утворення іншого органу в системі судової влади. Крім того, внесення зазначених змін зумовить істотні зміни у взаємодії ВРП і ВККС України. Адже, окрім добору кандидатів на посади судді ВККС України виконує ще й значну кількість інших пов'язаних функцій: веде облік даних про кількість посад суддів у судах, у т. ч. вакантних; визначає потреби у державному замовленні на професійну підготовку кандидатів на посаду судді у Національній школі суддів України; затверджує форму і зміст заяви про участь у доборі кандидатів на посаду судді, анкети кандидата на посаду судді, порядок складення відбіркового іспиту та методику оцінювання його результатів, порядок проходження спеціальної підготовки кандидатів на посаду судді, порядок складення кваліфікаційного іспиту та методику оцінювання кандидатів, положення про проведення конкурсу на зайняття вакантної посади судді, порядок і методологію кваліфікаційного оцінювання, порядок формування і ведення суддівського досьє (досьє кандидата на посаду судді) та інші процедури виконання Комісією iї функцій; бере у межах компетенції участь у міжнародному співробітництві, у т. ч. встановлює зв'язки з іноземними закладами, установами й організаціями, проектами міжнародної технічної допомоги, є бенефіціаром, реципієнтом міжнародної технічної допомоги, головним розпорядником міжнародної допомоги від іноземних держав, банків і міжнародних фінансових організацій тощо (ч. 1 ст. 93 Закону «Про судоустрій і статус суддів»).

Попри наведене, результат зазначених законодавчих змін вбачається вартим їх проведення. Одними 3 перших кроків у зазначеному напрямі необхідно визначити: виключення із Закону «Про судоустрій і статус суддів» глави 3 розділу 5 та перенесення відповідних положень до Закону «Про Вищу раду правосуддя»; внесення змін до власне норм цієї глави виходячи зі статусу ВККС України як структурного підрозділу ВРП; внесення змін до інших положень Закону «Про судоустрій і статус суддів» із метою врахування змін у статусі ВККС України.

Висновки. Виходячи із вказаного, наведений у юридичній літературі поділ суб'єктів формування суддівського корпусу за комплексним критерієм мети та правових наслідків діяльності на попередні (кваліфікаційні комісії) та безпосередні (суб’єкти остаточного

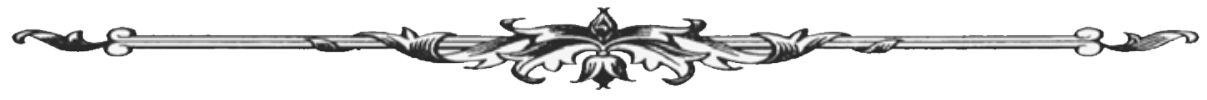


призначення на посаду судді) необхідно визнати таким, що поступово втрачає свою актуальність як із наукового, так і з практичного погляду, не відповідає визнаним міжнародним стандартам побудови суб'єктів призначення на посаду судді.

Реалізація передання повноважень ВККС України щодо проведення добору кандидатів для призначення на посаду судді, у тому числі організації проведення щодо них спеціальної перевірки відповідно до закону та прийняття кваліфікаційного іспиту передбачає внесення комплексних змін до чинного законодавства про судоустрій. Втім, одним із перших кроків необхідно визначити: виключення із Закону «Про судоустрій і статус суддів» глави 3 розділу 5 та перенесення відповідних положень до Закону «Про Вищу раду правосуддя»; внесення змін до власне норм цієї глави виходячи зі статусу ВККС України як структурного підрозділу ВРП; внесення змін до інших положень Закону «Про судоустрій і статус суддів» із метою врахування змін у статусі ВККС України.

\section{Список використаних джерел:}

1. Президент Володимир Зеленський підписав Закон «Про внесення змін до деяких законів України щодо діяльності органів суддівського врядування». Укрінформ - актуальні новини України та світу. URL: https://www.ukrinform.ua/rubric-polytics/2811485-zelenskijpidpisav-zakon-pro-sudovu-reformu.html (дата звернення: 10.11.2019).

2. Свропейські та міжнародні стандарти у сфері судочинства. Київ, 2015. 708 с.

3. Загальна декларація прав людини від 10 грудня 1948 р. Офіційний вісник Украӥни. 2008. № 93. Ст. 3103.

4. Конвенція про захист прав людини і основоположних свобод від 04 листопада 1950 № ETS № 005. Офіиійний вісник Украӥни. 1998. № 13.

5. Посібник зі статті 6. Право на справедливий суд (цивільна частина). https://www. echr.coe.int/Documents/Guide_Art_6_UKR.pdf (дата звернення: 05.11.2019).

6. Про Вищу раду правосуддя : Закон України від 21 грудня 2016 р. № 1798-VIII. Офіиійний вісник України. 2017. № 4. Ст. 107.

7. За наслідками кваліфікаційного оцінювання звільнено лише 15 суддів. Громадськість назвала основні недоліки оцінювання. Фундація DEJURE. URL: https://dejure. foundation/news/za-naslidkamy-kvalifikaciynogo-ociniuvannia-zvilneno-lyshe-15-suddiv (дата звернення: 06.11.2019).

8. Передумали? Перенесений розгляд справи скандального судді Чванкіна зник 3 розкладу на сайті ВККСУ. Інформаційний портал «СтопКор». URL: https:/stopcor.org/ peredumali-pereneseniy-rozglyad-spravi-skandalnogo-suddi-chvankina-znik-z-rozkladu-na-saytivkksu/ (дата звернення: 05.11.2019).

9. Берко С. Веселі старти президента Зеленського у судах. Украӥнська правда. URL: https://www.pravda.com.ua/columns/2019/10/16/7229239/ (дата звернення: 05.11.2019).

10. Конституція України. Науково-практичний коментар / за ред. В.Я. Тація, О.В. Петришина, Ю.Г. Барабаша та ін. Харків : Право, 2011. 1128 с.

11. Організація судових та правоохоронних органів : підручник / за ред. І.С. Марочкіна. Харків : Право, 2013. 448 с.

12. Прилуцький С.В. Формування корпусу професійних суддів України : дис. ... канд. юрид. наук : 12.00.10. НАН України, Інститут держави і права ім. В.М. Корецького. Київ, 2003. $223 \mathrm{c}$.

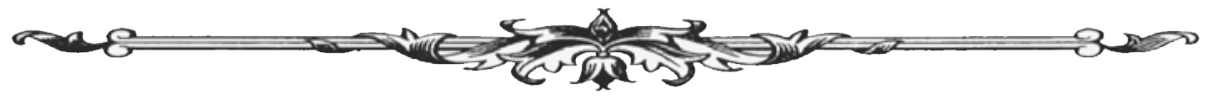

